\title{
Partial Molar Volume of Mefenamic Acid in Alcohol at Temperatures between T=293.15 and $\mathrm{T}=313.15 \mathrm{~K}$
}

\author{
Muhammad J. Iqbal* and Mahrukh Siddiquah
}

\author{
Department of Chemistry, Quaid-i-Azam University, Islamabad 45320, Pakistan
}

\begin{abstract}
Volume molar aparente $\left(V_{\Phi}\right)$, volume molar parcial $(\bar{V})$, parâmetro de interação solutosoluto $\left(S_{\mathrm{v}}\right)$, expansividade molar parcial $\left(E_{2}^{0}\right)$ e coeficiente de expansão térmica isobárica $\left(\alpha_{2}\right)$ do ácido mefenâmico em seis diferentes solventes orgânicos : metanol, etanol, 1-propanol, 2propanol, 1-butanol e 2-butanol, foram calculados a partir das densidades das soluções medidas no intervalo de temperatura entre 293,15 e $313,15 \pm 0,1 \mathrm{~K}$. As densidades das soluções foram medidas por um densímetro automatizado (Anton Paar DMA-48). O intervalo de concentração investigado foi de $6,00 \times 10^{-3}$ a $3,25 \times 10^{-2} \mathrm{~mol} \mathrm{~kg}^{-1}$. O efeito da temperatura sobre o volume molar aparente e o volume molar parcial foi também determinado. Um decréscimo nas interações soluto-solvente foi observado com o aumento da temperatura. O volume molar parcial do ácido mefenâmico também varia com a variação da polaridade do solvente.
\end{abstract}

Apparent molar volume $\left(V_{\Phi}\right)$, partial molar volume $(\bar{V})$, solute-solute interaction parameter $\left(S_{\mathrm{v}}\right)$, partial molar expansivity $\left(E_{2}^{0}\right)$ and isobaric thermal expansion coefficient $\left(\alpha_{2}\right)$ of mefenamic acid in six different organic solvents namely, methanol, ethanol, 1-propanol, 2-propanol, 1-butanol, and 2-butanol, have been calculated from the measured solution densities over a temperature range of $\mathrm{T}=293.15$ and $\mathrm{T}=313.15 \pm 0.1 \mathrm{~K}$. The solution densities were measured by an automated vibrating tube densitymeter (Anton Paar DMA-48). The molality range investigated was between $6 \times 10^{-3}$ and $3.25 \times 10^{-2} \mathrm{~mol} \mathrm{~kg}^{-1}$. The effect of temperature on apparent molar volume and partial molar volume was also determined. Decrease in solute-solvent interactions with an increase in temperature has been noted. Partial molar volume of mefenamic acid changes with the change in solvent polarity.

Keywords: apparent molar volume, partial molar volume, mefenamic acid, partial molar expansivity, alcohol

\section{Introduction}

In biophysical chemistry drug-macromolecular interaction is an important phenomenon involving complex molecular mechanism. Perceptible thermodynamic changes are found to be associated with the processes of drug transport, ${ }^{1}$ drug-protein binding, ${ }^{2}$ anesthesia ${ }^{3}$ etc. In the case of drug-protein binding, anomalous behaviour has been observed with respect to certain drugs. ${ }^{4}$ Because of the complexities associated with the structure of biomacromolecules or with their data interpretation, it is difficult to carry out these processes in physiological media. Consequently, it is imperative that each component of these systems may be studied individually before going to more complex systems. Thermodynamic methods are well recognized and convenient for studying the molecular

*e-mail: mjiqauchem@yahoo.com interactions in fluids. The partial molar volume, pressure derivative of Gibbs energy, is a useful parameter for interpreting solute-solvent interactions. ${ }^{5,6}$ Comparison of the volume of the system with those of its components can assess gross changes in the volume of the system because it is an additive property. In addition, volumetric data can also be interpreted in terms of molecular interactions within the system. Various molecular processes in solutions such as electrostriction, ${ }^{7}$ hydrophobic hydration, ${ }^{8}$ micellization and co-sphere overlap during solute-solute interactions have been interpreted, to a large extent, from the partial molar volume data of many compounds including amino acids, peptides and also some drug compounds. ${ }^{5}$

Mefenamic acid is known as an antipathologistic analgesic and provides relief of mild to moderate pain, especially pain after surgery and fever. Mefenamic acid is known to strongly bind to the plasma protein. ${ }^{9}$ As a part of the longer-term objective to investigate thermodynamic aspects of biochemical processes involving such drug- 
macromolecule interactions, the results of the determinations of apparent molar volumes $\left(V_{\Phi}\right)$, partial molar volume $(\bar{V})$, solute-solvent interaction parameter $\left(S_{\mathrm{v}}\right)$, partial molar expansivity $\left(E_{2}^{0}\right)$ and isobaric thermal expansion coefficient $\left(\alpha_{2}\right)$ of mefenamic acid in six different organic solvents i.e. methanol, ethanol, 1-propanol, 2-propanol, 1-butanol, and 2-butanol between $\mathrm{T}=293.15$ and $\mathrm{T}=313.15 \pm 0.1 \mathrm{~K}$ are reported in the present study.

\section{Materials and Methods}

Mefenamic acid (N-(2,3-xylyl) anthranilic acid, molar mass $=241.3 \mathrm{~g} \mathrm{~mol}^{-1}$ ) used in this study was supplied by Sigma $(99.3 \%)$. The structural formula of mefenamic acid is:

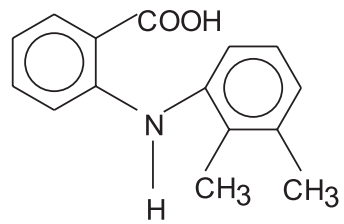

\section{$\mathrm{N}-(2,3-x y l y l)$ anthranilic acid}

The solvents used were methanol (99\%, Merck), ethanol (99\%, Acros Organics), 1-propanol (99\%, Fluka), 2-propanol (99\%, Fluka), 1-butanol (99\%, Fluka), and 2-butanol (99\%, Fluka). Since values for the density of the pure solvents measured at $\mathrm{T}=293.15 \mathrm{~K}$ were comparable with the literature value $^{10}$ as shown in Table 1 , therefore the solvents were used without further purification. Molal solutions of mefenamic acid were prepared using $\mathrm{m} / \mathrm{m} \%$ method in calibrated flasks at $\mathrm{T}=293.15 \mathrm{~K}$. The molality range studied was between $m=6.00 \times 10^{-3} \pm 10^{-5} \mathrm{~mol} \mathrm{~kg}{ }^{-1}$ and $m=3.25 \times 10^{-2} \pm 10^{-5} \mathrm{~mol} \mathrm{~kg}{ }^{-1}$. Solutions were prepared immediately prior to measurements by addition of stiochiometric quantity of mefenamic acid to the solvents. The density of various solutions was measured using an automated vibrating tube density meter (Anton Paar DMA 48), with an uncertainty of $\pm 0.0001 \mathrm{~g} \mathrm{~cm}^{-3}$, which was calibrated with air and doubly distilled water in the temperature range investigated. The density measurements were made at different temperatures i.e. $\mathrm{T}=293.15,298.15$, $303.15,308.15,310.65$ and $\mathrm{T}=313.15 \pm 0.1 \mathrm{~K}$. Apparent molar volume of mefenamic acid was calculated using the following equation: ${ }^{11}$

$V_{\Phi}=\frac{\left(\rho_{0}-\rho\right)}{m \rho \rho_{0}}+\frac{M_{2}}{\rho}$

Where $\rho_{0}=$ density of pure component 1 (solvent), $\rho=$ density of solution of molality $m$ of mefenamic acid having molar mass $\mathbf{M}_{2}$.

Apparent molar volume $\left(V_{\Phi}\right)$ of mefenamic acid was then plotted against the molality $(m)$ in different organic solvents i.e. methanol, 1-butanol, 2-butanol and DMF in accordance with equation (2)

$V_{\Phi}=\bar{V}+S_{v} m+S_{v v} m^{2}+\ldots$

where $S_{\mathrm{v}}, S_{\mathrm{vv}}$ are the empirical parameters which depend on solvent, solute and the temperature ${ }^{12}$ and $\bar{V}$ is the partial molar volume of the solute molecule in the specific solvent. The values of $\bar{V}$ and correlation coefficients have been estimated by the least-square fitting of the apparent molar volume data in the equation (2). Only two parameters of equation (2) i.e. partial molar volume $(\bar{V})$ and solute-solute interaction parameter $\left(S_{\mathrm{v}}\right)$, were considered to be sufficient to represent the data adequately.

The values of partial molar expansivity were then calculated $^{13}$ from the partial molar volume by the relation:

$E_{2}^{0}=\left(\frac{\partial \bar{V}}{\partial T}\right)_{p}$

Since the changes in the solution structure are very sensitive to temperature changes, the partial molar expansion is a sensitive criterion for the detection of solutesolvent interactions.

Table 1. Density $(\rho)$ of different solvents measured at $293.15 \pm 0.1 \mathrm{~K}$ and their literature values ${ }^{10}$

\begin{tabular}{|c|c|c|c|c|c|c|c|}
\hline \multirow[t]{2}{*}{ Solvents } & \multirow[t]{2}{*}{$\begin{array}{c}\text { Reported } \\
\text { Values }\end{array}$} & \multicolumn{5}{|c|}{$\begin{array}{l}\text { Experimentally Determined Values } \\
\qquad \rho /\left(\mathrm{g} \mathrm{cm}^{-3}\right)\end{array}$} & \multirow[t]{2}{*}{$\begin{array}{l}\text { Av. } \\
\text { Value }\end{array}$} \\
\hline & & 1 & 2 & 3 & 4 & 5 & \\
\hline Water & 0.9982 & 0.9982 & 0.9982 & 0.9982 & 0.9981 & 0.9982 & 0.9981 \\
\hline Toluene & 0.8669 & 0.8670 & 0.8669 & 0.8669 & 0.8669 & 0.8670 & 0.8669 \\
\hline Cyclohexane & 0.7785 & 0.7785 & 0.7785 & 0.7785 & 0.7785 & 0.7785 & 0.8875 \\
\hline Methanol & 0.7914 & 0.7917 & 0.7918 & 0.7917 & 0.7918 & 0.7916 & 0.7917 \\
\hline Ethanol & 0.7893 & 0.7904 & 0.7906 & 0.7905 & 0.7905 & 0.7905 & 0.7905 \\
\hline 1-Propanol & 0.8035 & 0.8044 & 0.8044 & 0.8043 & 0.8043 & 0.8043 & 0.8043 \\
\hline 2-Propanol & 0.7855 & 0.7852 & 0.7851 & 0.7852 & 0.7853 & 0.7853 & 0.7852 \\
\hline 1-Butanol & 0.8098 & 0.8100 & 0.8100 & 0.8100 & 0.8100 & 0.8100 & 0.8100 \\
\hline 2-Butanol & 0.8063 & 0.8070 & 0.8071 & 0.8071 & 0.8071 & 0.8072 & 0.8071 \\
\hline
\end{tabular}


From the partial molar volume $(\bar{V})$ data, the isobaric thermal expansion coefficient of solute at infinite dilution, $\alpha_{2}$ was also calculated, by the following equation: ${ }^{14}$

$\alpha_{2}=\frac{1}{\bar{V}}\left(\frac{\partial \bar{V}}{\partial T}\right)_{P}=\frac{E_{2}^{0}}{\bar{V}}$

\section{Results and Discussion}

The apparent molar volume data for mefenamic acid dissolved in methanol, ethanol, 1-propanol, 2-propanol, 1-butanol and 2-butanol (Figures 1-6) increases with concentration at a particular temperature. The apparent molar volume of mefenamic acid at a constant concentration decreases with an increase in temperature of the system in all the solvents (Tables 2-7). The slope of the lines, drawn in accordance with equation (2), resulted in positive values of $S_{\mathrm{v}}$ for all the solutions. In case of positive $S_{\mathrm{v}}$ values (Table 8), the solvent molecules are believed to be more structured in the bulk phase than in the solvation sphere and an increase in the concentration of the drug compound results in the release of solvent molecules from the solvation shell into the bulk solvent that is more structured. ${ }^{13}$ The characteristic of the co-sphere depends upon the drug structure, size, shape and solvophobicity. ${ }^{14}$ Table 8 shows that the partial molar volume $(\bar{V})$, partial molar expansivity $\left(E_{2}^{0}\right)$ and isobaric thermal expansion coefficient $\left(\alpha_{2}\right)$ are independent of concentration and that the values of $\bar{V}$ for mefenamic acid increase with rise in temperature in all the solvents employed here.

According to the scaled particle theory (SP), ${ }^{15}$ the expression for the partial molar volume of a solute at infinite dilution is given as follows:

$\bar{V}=V_{c a v}+V_{\text {int }}+\beta^{0} R T$

Where $V_{c a v}$ and $V_{i n t}$ are the contributions for the formation of a cavity and from intermolecular interactions respectively, $\beta^{0}$ is the isothermal compressibility of the solvent, $\mathrm{R}$ is the gas constant and $\mathrm{T}$ is the absolute temperature. The creation of a cavity is by definition a positive contribution to the partial molar volume of a solute, whereas the attractive intermolecular solute-solvent interactions cause a negative contribution by shrinking the cavity. The results are also viewed in terms of the geometrical fit of the drug molecules in an ordered solvent. It is difficult to accommodate a complex structured solute such as mefenamic acid in an ordered solvent environment like alcohols. As the temperature of the solution is increased, cavities are produced in the ordered solvent environment, resulting in the better fit of the complex structured solutes in the solvent. With increasing temperature the contribution from the drug-solvent binding is weakened and the partial molar volume of the drug compounds increases significantly with temperature. It is apparent from Table 8 that $S_{\mathrm{v}}$ values showed somewhat irregular change with increasing temperature.

The isobaric thermal expansion coefficient $\left(\alpha_{2}\right)$ for mefenamic acid obtained from equation (4) showed a decreasing behaviour with increasing temperature in all the solvents studied in the present work because when the temperature is increased the density of the solution decreased (Tables 2-7), resulting in a decrease in partial molar expansivity coefficient $\left(\alpha_{2}\right)$. A similar trend was observed by Iqbal and Verrall ${ }^{5}$ for aqueous solutions of compounds having more than one $\mathrm{OH}$ - group, whereas the opposite effect for mono-functional alcohols was observed by Neal and Goring. ${ }^{16}$ The largest value of the partial molar volume was obtained in 2-butanol while its value was smallest in methanol as shown in Table 8 . The value of $\bar{V}$ is larger in 2-butanol as compared to that in 1-butanol (Table 8) with a transfer volume of $25.13 \pm 3.98$ $\mathrm{cm}^{3} \mathrm{~mol}^{-1}$ in the studied temperature range. The difference in partial molar volume of mefenamic acid in 1- and 2-butanol is considered to be due to differences in the structure of the two solvents in their solvation pattern. For instance, 1-butanol displaying straight chain showed self-association ${ }^{17}$ to a much greater extent in comparison to 2-butanol. The number of molecules in 1-butanol aggregates is greater as compared to the aggregates of 2-butanol. The extent to which 1-butanol molecules are bonded to one another in 1-butanol is higher than that in 2-butanol. This resulted in larger partial molar volume of mefenamic acid in 1-butanol than in 2-butanol. Same is the reason for the higher value of partial molar expansivity of the drug compound in two solvents.

Partial molar volume of mefenamic acid was plotted as a function of solvent dielectric constant, which is a measure of solvent polarity as shown in Figure 8. It is evident that the partial molar volume of mefenamic acid decrease with increase in the solvent polarity. This indicates that by increasing solvent polarity, the solutesolvent interactions are decreased.

The partial molar volume of mefenamic acid was then plotted against the temperature in accordance with equation (3) (Figure 7) and the values of partial molar expansivity of mefenamic acid in different solvents were obtained (Table 9). Highest value of partial molar expansivity $\left(E_{2}^{0}\right)$ of mefenamic acid $(0.2262 \pm 0.0001$ $\mathrm{cm}^{3} \mathrm{~mol}^{-1} \mathrm{~K}^{-1}$ ) was obtained for 1-propanol as compared 


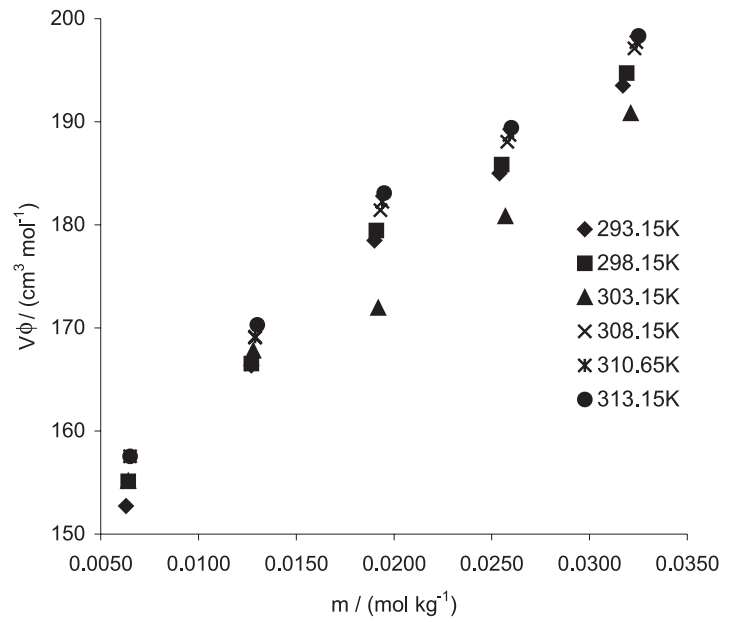

Figure 1. Apparent molar volume $\left(V_{\Phi}\right)$ as a function of molality $(\mathrm{m})$ of mefenamic acid in methanol at temperatures between $\mathrm{T}=293.15$ and $\mathrm{T}=313.15 \mathrm{~K}$

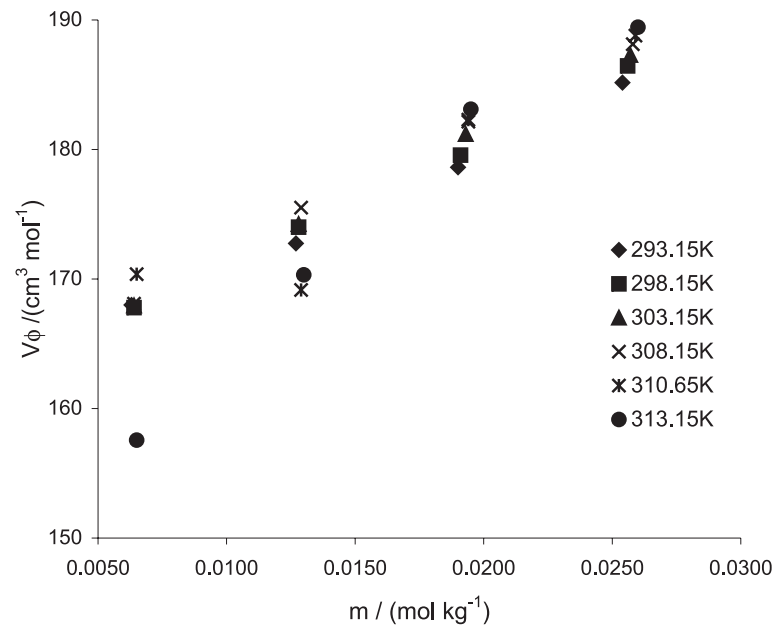

Figure 2. Apparent molar volume $\left(V_{\Phi}\right)$ as a function of molality $(\mathrm{m})$ of mefenamic acid in ethanol at temperatures between $\mathrm{T}=293.15$ and $\mathrm{T}=313.15 \mathrm{~K}$.

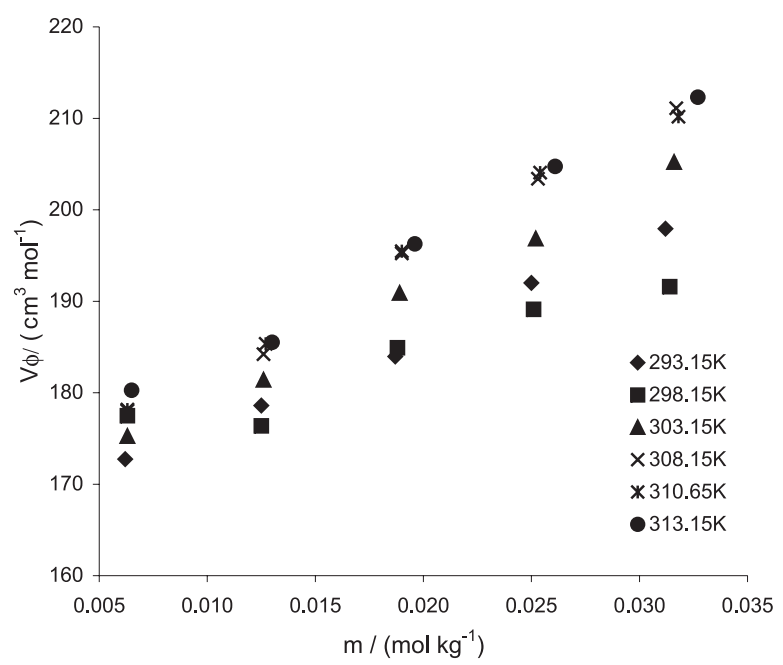

Figure 3. Apparent molar volume $\left(V_{\Phi}\right)$ as a function of molality (m) of mefenamic acid in 1-propanol at temperatures between $\mathrm{T}=293.15$ and $\mathrm{T}=313.15 \mathrm{~K}$.

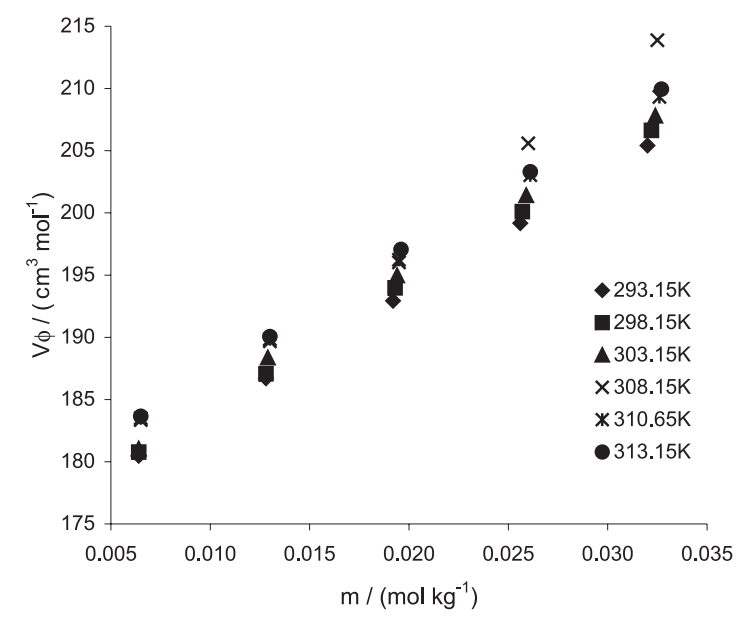

Figure 4. Apparent molar volume $\left(V_{\Phi}\right)$ as a function of molality $(\mathrm{m})$ of mefenamic acid in 2-propanol at temperatures between $\mathrm{T}=293.15$ and $\mathrm{T}=313.15 \mathrm{~K}$.

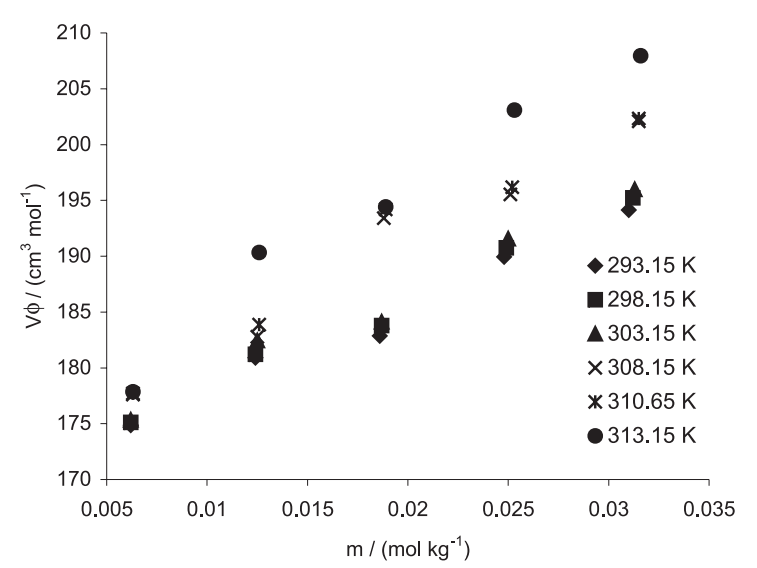

Figure 5. Apparent molar volume $\left(V_{\Phi}\right)$ as a function of molality (m) of mefenamic acid in 1-butanol at temperatures between $\mathrm{T}=293.15$ and $\mathrm{T}=313.15 \mathrm{~K}$.

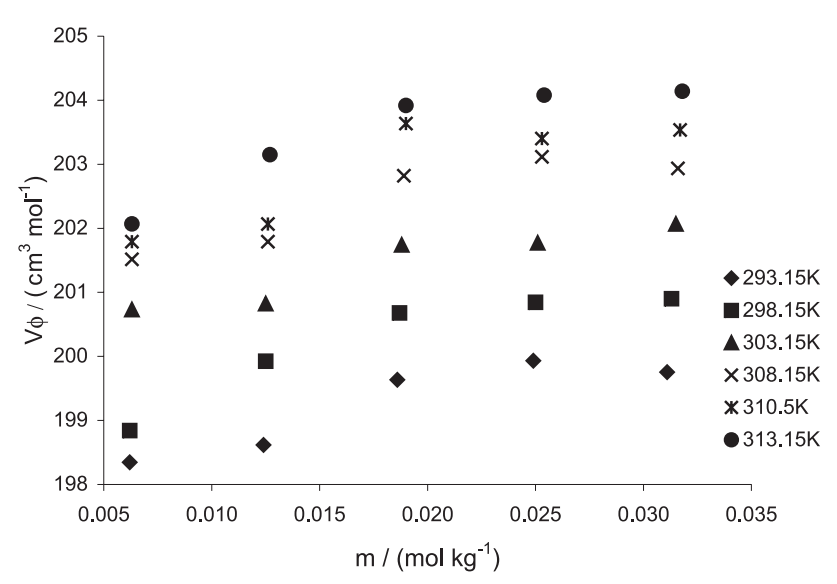

Figure 6. Apparent molar volume $\left(V_{\Phi}\right)$ as a function of molality $(\mathrm{m})$ of mefenamic acid in 2-butanol at temperatures between $\mathrm{T}=293.15$ and $\mathrm{T}=313.15 \mathrm{~K}$. 
Table 2. Calculated values of the apparent molar volume $\left(V_{\Phi}\right)( \pm 0.01)$ of mefenamic acid in methanol at $293.15-313.15 \pm 0.1 \mathrm{~K}$

\begin{tabular}{|c|c|c|c|c|c|c|c|}
\hline $\mathrm{T} /(\mathrm{K})$ & $m /\left(\mathrm{mol} \mathrm{kg}^{-1}\right)$ & $\rho /\left(\mathrm{g} \mathrm{cm}^{-3}\right)$ & $V_{\Phi} /\left(\mathrm{cm}^{3} \mathrm{~mol}^{-1}\right)$ & $\mathrm{T} /(\mathrm{K})$ & $m /\left(\mathrm{mol} \mathrm{kg}^{-1}\right)$ & $\rho /\left(\mathrm{g} \mathrm{cm}^{-3}\right)$ & $V_{\Phi} /\left(\mathrm{cm}^{3} \mathrm{~mol}^{-1}\right)$ \\
\hline \multirow[t]{6}{*}{313.15} & 0.0000 & 0.7728 & & 310.65 & 0.0000 & 0.7752 & \\
\hline & 0.0065 & 0.7734 & 157.56 & & 0.0065 & 0.7758 & 157.55 \\
\hline & 0.0130 & 0.7739 & 170.32 & & 0.0129 & 0.7763 & 169.14 \\
\hline & 0.0195 & 0.7743 & 183.08 & & 0.0194 & 0.7767 & 182.26 \\
\hline & 0.0260 & 0.7747 & 189.41 & & 0.0259 & 0.7771 & 188.74 \\
\hline & 0.0325 & 0.7750 & 198.33 & & 0.0324 & 0.7774 & 197.72 \\
\hline \multirow[t]{6}{*}{308.15} & 0.0000 & 0.7776 & & 303.15 & 0.0000 & 0.7823 & \\
\hline & 0.0064 & 0.7782 & 155.15 & & 0.0064 & 0.7829 & 155.14 \\
\hline & 0.0129 & 0.7787 & 169.05 & & 0.0128 & 0.7834 & 167.79 \\
\hline & 0.0193 & 0.7791 & 181.43 & & 0.0192 & 0.7839 & 171.93 \\
\hline & 0.0258 & 0.7795 & 188.06 & & 0.0257 & 0.7843 & 180.83 \\
\hline & 0.0323 & 0.7798 & 197.11 & & 0.0321 & 0.7846 & 190.81 \\
\hline \multirow[t]{6}{*}{298.15} & 0.0000 & 0.7870 & & 293.15 & 0.0000 & 0.7917 & \\
\hline & 0.0064 & 0.7876 & 155.13 & & 0.0063 & 0.7923 & 152.73 \\
\hline & 0.0127 & 0.7881 & 166.53 & & 0.0127 & 0.7928 & 166.37 \\
\hline & 0.0191 & 0.7885 & 179.47 & & 0.0190 & 0.7932 & 178.49 \\
\hline & 0.0255 & 0.7889 & 185.86 & & 0.0254 & 0.7936 & 185.00 \\
\hline & 0.0319 & 0.7892 & 194.72 & & 0.0317 & 0.7939 & 193.53 \\
\hline
\end{tabular}

Table 3. Calculated values of the apparent molar volume $\left(V_{\Phi}\right)( \pm 0.01)$ of mefenamic acid in ethanol at $293.15-313.15 \pm 0.1 \mathrm{~K}$

\begin{tabular}{|c|c|c|c|c|c|c|c|}
\hline $\mathrm{T} /(\mathrm{K})$ & $m /\left(\mathrm{mol} \mathrm{kg}^{-1}\right)$ & $\rho /\left(\mathrm{g} \mathrm{cm}^{-3}\right)$ & $V_{\Phi} /\left(\mathrm{cm}^{3} \mathrm{~mol}^{-1}\right)$ & $\mathrm{T} /(\mathrm{K})$ & $m /\left(\mathrm{mol} \mathrm{kg}{ }^{-1}\right)$ & $\rho /\left(\mathrm{g} \mathrm{cm}^{-3}\right)$ & $V_{\Phi} /\left(\mathrm{cm}^{3} \mathrm{~mol}^{-1}\right)$ \\
\hline \multirow[t]{6}{*}{313.15} & 0.0000 & 0.7724 & & 310.65 & 0.0000 & & \\
\hline & 0.0065 & 0.7730 & 170.45 & & 0.0065 & 0.7752 & 170.37 \\
\hline & 0.0130 & 0.7735 & 176.78 & & 0.0129 & 0.7757 & 175.62 \\
\hline & 0.0195 & 0.7739 & 183.11 & & 0.0194 & 0.7761 & 182.30 \\
\hline & 0.0260 & 0.7743 & 189.45 & & 0.0259 & 0.7765 & 188.79 \\
\hline & 0.0325 & 0.7747 & 193.21 & & 0.0324 & 0.7769 & 192.63 \\
\hline \multirow[t]{6}{*}{308.15} & 0.0000 & 0.7768 & & 303.15 & 0.0000 & 0.7812 & \\
\hline & 0.0064 & 0.7774 & 168.10 & & 0.0064 & 0.7818 & 167.95 \\
\hline & 0.0129 & 0.7779 & 175.51 & & 0.0128 & 0.7823 & 174.23 \\
\hline & 0.0194 & 0.7783 & 182.15 & & 0.0193 & 0.7827 & 181.18 \\
\hline & 0.0258 & 0.7787 & 188.13 & & 0.0257 & 0.7831 & 187.29 \\
\hline & 0.0323 & 0.7791 & 192.57 & & 0.0322 & 0.7835 & 191.28 \\
\hline \multirow[t]{6}{*}{298.15} & 0.0000 & 0.7856 & & 293.15 & 0.0000 & 0.7898 & \\
\hline & 0.0064 & 0.7862 & 167.79 & & 0.0063 & 0.7903 & 167.99 \\
\hline & 0.0128 & 0.7867 & 174.01 & & 0.0127 & 0.7909 & 172.75 \\
\hline & 0.0191 & 0.7871 & 179.56 & & 0.0190 & 0.7913 & 178.62 \\
\hline & 0.0256 & 0.7875 & 186.45 & & 0.0254 & 0.7917 & 185.16 \\
\hline & 0.0320 & 0.7879 & 190.14 & & 0.0318 & 0.7921 & 189.02 \\
\hline
\end{tabular}

Table 4. Calculated values of the apparent molar volume $\left(V_{\Phi}\right)( \pm 0.01)$ of mefenamic acid in 1-propanol at 293.15-313.15 $\pm 0.1 \mathrm{~K}$

\begin{tabular}{lccccccc}
\hline $\mathrm{T} /(\mathrm{K})$ & $m /\left(\mathrm{mol} \mathrm{kg}^{-1}\right)$ & $\rho /\left(\mathrm{g} \mathrm{cm}^{-3}\right)$ & $V_{\Phi} /\left(\mathrm{cm}^{3} \mathrm{~mol}^{-1}\right)$ & $\mathrm{T} /(\mathrm{K})$ & $m /\left(\mathrm{mol} \mathrm{kg}^{-1}\right)$ & $\rho /\left(\mathrm{g} \mathrm{cm}^{-3}\right)$ & $V_{\Phi} /\left(\mathrm{cm}^{3} \mathrm{~mol}^{-1}\right)$ \\
\hline 313.15 & 0.0000 & 0.7881 & & 310.65 & 0.0000 & 0.7902 & \\
& 0.0064 & 0.7886 & 180.28 & & 0.0063 & 0.7907 & 178.15 \\
& 0.0127 & 0.7891 & 185.52 & & 0.0127 & 0.7912 & 185.35 \\
& 0.0191 & 0.7894 & 196.27 & & 0.0190 & 0.7915 & 195.47 \\
& 0.0255 & 0.7897 & 204.74 & & 0.0254 & 0.7918 & 204.07 \\
308.15 & 0.0319 & 0.7900 & 212.31 & & 0.0318 & 0.7921 & 210.19 \\
& 0.0000 & 0.7923 & & 303.15 & 0.0000 & 0.7963 & \\
& 0.0063 & 0.7928 & 178.01 & & 0.0063 & 0.7968 & 175.25 \\
& 0.0126 & 0.7933 & 184.23 & & 0.0126 & 0.7973 & 181.40 \\
& 0.0190 & 0.7936 & 195.24 & & 0.0189 & 0.7976 & 190.89 \\
& 0.0253 & 0.7939 & 203.40 & & 0.0252 & 0.7980 & 196.85 \\
& 0.0317 & 0.7942 & 211.10 & & 0.0316 & 0.7983 & 205.21 \\
& 0.0000 & 0.8003 & & 0.0000 & 0.8043 & \\
& 0.0063 & 0.8008 & 172.53 & & 0.0062 & 0.8048 & 172.75 \\
& 0.0125 & 0.8013 & 177.64 & & 0.0125 & 0.8053 & 178.60 \\
& 0.0188 & 0.8017 & 184.09 & & 0.0187 & 0.8057 & 183.96 \\
& 0.0251 & 0.8021 & 189.12 & & 0.0250 & 0.8060 & 192.01 \\
& 0.0314 & 0.8025 & 194.08 & & 0.0312 & 0.8064 & 197.94 \\
\hline
\end{tabular}


Table 5. Calculated values of the apparent molar volume $\left(V_{\Phi}\right)( \pm 0.01)$ of mefenamic acid in 2-propanol at 293.15-313.15 $\pm 0.1 \mathrm{~K}$

\begin{tabular}{|c|c|c|c|c|c|c|c|}
\hline $\mathrm{T} /(\mathrm{K})$ & $m /\left(\mathrm{mol} \mathrm{kg}^{-1}\right)$ & $\rho /\left(\mathrm{g} \mathrm{cm}^{-3}\right)$ & $V_{\Phi} /\left(\mathrm{cm}^{3} \mathrm{~mol}^{-1}\right)$ & $\mathrm{T} /(\mathrm{K})$ & $m /\left(\mathrm{mol} \mathrm{kg}^{-1}\right)$ & $\rho /\left(\mathrm{g} \mathrm{cm}^{-3}\right)$ & $V_{\Phi} /\left(\mathrm{cm}^{3} \mathrm{~mol}^{-1}\right)$ \\
\hline \multirow[t]{6}{*}{313.15} & 0.0000 & 0.7680 & & 310.65 & 0.0000 & 0.7703 & \\
\hline & 0.0065 & 0.7685 & 183.66 & & 0.0065 & 0.7708 & 183.50 \\
\hline & 0.0130 & 0.7690 & 190.06 & & 0.0130 & 0.7713 & 189.86 \\
\hline & 0.0196 & 0.7694 & 197.07 & & 0.0195 & 0.7717 & 196.24 \\
\hline & 0.0261 & 0.7697 & 203.31 & & 0.0261 & 0.7720 & 203.04 \\
\hline & 0.0327 & 0.7700 & 209.95 & & 0.0326 & 0.7723 & 209.32 \\
\hline \multirow[t]{6}{*}{308.15} & 0.0000 & 0.7724 & & 303.15 & 0.0000 & 0.7768 & \\
\hline & 0.0065 & 0.7729 & 183.35 & & 0.0064 & 0.7773 & 181.05 \\
\hline & 0.0130 & 0.7734 & 189.68 & & 0.0129 & 0.7778 & 188.36 \\
\hline & 0.0195 & 0.7738 & 196.02 & & 0.0194 & 0.7782 & 194.97 \\
\hline & 0.0260 & 0.7741 & 205.59 & & 0.0259 & 0.7785 & 201.42 \\
\hline & 0.0325 & 0.7743 & 213.89 & & 0.0324 & 0.7788 & 207.80 \\
\hline \multirow[t]{6}{*}{298.15} & 0.0000 & 0.7808 & & 293.15 & 0.0000 & 0.7852 & \\
\hline & 0.0064 & 0.7813 & 180.78 & & 0.0064 & 0.7857 & 180.48 \\
\hline & 0.0128 & 0.7818 & 187.07 & & 0.0128 & 0.7862 & 186.71 \\
\hline & 0.0193 & 0.7822 & 193.97 & & 0.0192 & 0.7866 & 192.94 \\
\hline & 0.0257 & 0.7825 & 200.11 & & 0.0256 & 0.7869 & 199.17 \\
\hline & 0.0322 & 0.7828 & 206.63 & & 0.0320 & 0.7872 & 205.41 \\
\hline
\end{tabular}

Table 6. Calculated values of the apparent molar volume $\left(V_{\Phi}\right)( \pm 0.01)$ of mefenamic acid in 1-butanol at $293.15-313.15 \pm 0.1 \mathrm{~K}$

\begin{tabular}{lccccccc}
\hline $\mathrm{T} /(\mathrm{K})$ & $m /\left(\mathrm{mol} \mathrm{kg}^{-1}\right)$ & $\rho /\left(\mathrm{g} \mathrm{cm}^{-3}\right)$ & $V_{\Phi} /\left(\mathrm{cm}^{3} \mathrm{~mol}^{-1}\right)$ & $\mathrm{T} /(\mathrm{K})$ & $m /\left(\mathrm{mol} \mathrm{kg}^{-1}\right)$ & $\rho /\left(\mathrm{g} \mathrm{cm}^{-3}\right)$ & $V_{\Phi} /\left(\mathrm{cm}^{3} \mathrm{~mol}^{-1}\right)$ \\
\hline 313.15 & 0.0000 & 0.7946 & & 310.65 & 0.0000 & 0.7967 \\
& 0.0063 & 0.7951 & 177.86 & & 0.0063 & 0.7972 & 177.73 \\
& 0.0126 & 0.7955 & 190.33 & & 0.0126 & 0.7977 & 183.87 \\
& 0.0189 & 0.7959 & 194.42 & & 0.0189 & 0.7980 & 194.19 \\
& 0.0253 & 0.7962 & 203.10 & & 0.0252 & 0.7984 & 196.17 \\
308.15 & 0.0316 & 0.7965 & 207.95 & & 0.0315 & 0.7987 & 202.34 \\
& 0.0000 & 0.7986 & & 303.15 & 0.0000 & 0.8025 & 175.35 \\
& 0.0063 & 0.7991 & 177.60 & & 0.0062 & 0.8030 & 182.46 \\
& 0.0125 & 0.7996 & 182.77 & & 0.0125 & 0.8035 & 184.11 \\
& 0.0188 & 0.7999 & 193.41 & & 0.0187 & 0.8039 \\
\\
0.0251 & 0.8003 & 195.54 & & 0.0250 & 0.8043 & 191.57 \\
& 0.0315 & 0.8006 & 202.09 & & 0.0313 & 0.8046 & 195.99 \\
& 0.0000 & 0.8063 & & 0.0000 & 0.8100 & \\
& 0.0062 & 0.8068 & 175.11 & & 0.062 & 0.8105 & 174.88 \\
& 0.0124 & 0.8073 & 181.21 & & 0.0124 & 0.8110 & 180.92 \\
& 0.0187 & 0.8077 & 183.79 & & 0.0186 & 0.8114 & 182.86 \\
& 0.0249 & 0.8081 & 190.75 & & 0.0248 & 0.8118 & 189.94 \\
& 0.0312 & 0.8084 & 195.23 & & 0.0310 & 0.8121 & 194.15 \\
\hline
\end{tabular}

Table 7. Calculated values of the apparent molar volume $\left(V_{\Phi}\right)( \pm 0.01)$ of mefenamic acid in 2-butanol at 293.15-313.15 $\pm 0.1 \mathrm{~K}$

\begin{tabular}{|c|c|c|c|c|c|c|c|}
\hline $\mathrm{T} /(\mathrm{K})$ & $m /\left(\mathrm{mol} \mathrm{kg}^{-1}\right)$ & $\rho /\left(\mathrm{g} \mathrm{cm}^{-3}\right)$ & $V_{\Phi} /\left(\mathrm{cm}^{3} \mathrm{~mol}^{-1}\right)$ & $\mathrm{T} /(\mathrm{K})$ & $m /\left(\mathrm{mol} \mathrm{kg}^{-1}\right)$ & $\rho /\left(\mathrm{g} \mathrm{cm}^{-3}\right)$ & $V_{\Phi} /\left(\mathrm{cm}^{3} \mathrm{~mol}^{-1}\right)$ \\
\hline \multirow[t]{6}{*}{313.15} & 0.00 & 0.7901 & & 310.65 & 0.0000 & 0.7923 & \\
\hline & 0.0063 & 0.7905 & 202.07 & & 0.0063 & 0.7927 & 201.79 \\
\hline & 0.0127 & 0.7909 & 203.15 & & 0.0126 & 0.7931 & 202.07 \\
\hline & 0.0190 & 0.7913 & 203.92 & & 0.0190 & 0.7935 & 203.64 \\
\hline & 0.0254 & 0.7917 & 204.08 & & 0.0253 & 0.7939 & 203.40 \\
\hline & 0.0318 & 0.7921 & 204.14 & & 0.0317 & 0.7943 & 203.54 \\
\hline \multirow[t]{6}{*}{308.15} & 0.0000 & 0.7925 & & 303.15 & 0.0000 & 0.7988 & \\
\hline & 0.0063 & 0.7949 & 201.52 & & 0.0063 & 0.7992 & 200.73 \\
\hline & 0.0126 & 0.7953 & 201.79 & & 0.0125 & 0.7996 & 200.82 \\
\hline & 0.0189 & 0.7957 & 202.82 & & 0.0188 & 0.8000 & 201.74 \\
\hline & 0.0253 & 0.7961 & 203.12 & & 0.0251 & 0.8004 & 201.77 \\
\hline & 0.0316 & 0.7965 & 202.94 & & 0.0315 & 0.8008 & 202.07 \\
\hline \multirow[t]{6}{*}{298.15} & 0.0000 & 0.8030 & & 293.15 & 0.0000 & 0.8071 & \\
\hline & 0.0062 & 0.8034 & 198.84 & & 0.0062 & 0.8075 & 198.35 \\
\hline & 0.0125 & 0.8038 & 199.93 & & 0.0124 & 0.8079 & 198.62 \\
\hline & 0.0187 & 0.8042 & 200.68 & & 0.0186 & 0.8083 & 199.63 \\
\hline & 0.0250 & 0.8046 & 200.84 & & 0.0249 & 0.8087 & 199.93 \\
\hline & 0.0313 & 0.8050 & 200.90 & & 0.0311 & 0.8091 & 199.75 \\
\hline
\end{tabular}


Table 8. Values of the partial molar volume $(\bar{V})$, isobaric thermal expansion coefficient $\left(\alpha_{2}\right)$ and solute-solute interaction parameter $\left(S_{\mathrm{v}}\right)$ of mefenamic acid in various organic solvents at $293.15-313.15 \mathrm{~K}$

\begin{tabular}{|c|c|c|c|c|c|c|c|c|c|}
\hline \multirow[t]{2}{*}{$\mathrm{T} /(\mathrm{K})$} & \multicolumn{3}{|c|}{ Methanol v/ $\alpha 2 / \mathrm{sv} /$} & \multicolumn{3}{|c|}{ Ethanol v/ $\alpha 2 / \mathrm{sv} /$} & \multicolumn{3}{|c|}{ 1-Propanol v/ $\alpha 2 / \mathrm{sv} /$} \\
\hline & $\begin{array}{c}\bar{V} \\
\left(\mathrm{~cm}^{3} \mathrm{~mol}^{-1}\right)\end{array}$ & $\begin{array}{c}\alpha_{2} \\
\left(\mathrm{~K}^{-1} 10^{-3}\right)\end{array}$ & $\begin{array}{c}S_{\mathrm{v}} \\
\left(\mathrm{cm}^{3} \mathrm{~mol}^{-2} \mathrm{~kg}\right)\end{array}$ & $\begin{array}{c}\bar{V} \\
\left(\mathrm{~cm}^{3} \mathrm{~mol}^{-1}\right)\end{array}$ & $\begin{array}{c}\alpha_{2} \\
\left(\mathrm{~K}^{-1} 10^{-3}\right)\end{array}$ & $\begin{array}{c}S_{\mathrm{v}} \\
\left(\mathrm{cm}^{3} \mathrm{~mol}^{-2} \mathrm{~kg}\right)\end{array}$ & $\begin{array}{c}\bar{V} \\
\left(\mathrm{~cm}^{3} \mathrm{~mol}^{-1}\right)\end{array}$ & $\begin{array}{c}\alpha_{2} \\
\left(\mathrm{~K}^{-1} 10^{-3}\right)\end{array}$ & $\begin{array}{c}S_{\mathrm{v}} \\
\left(\mathrm{cm}^{3} \mathrm{~mol}^{-2} \mathrm{~kg}\right)\end{array}$ \\
\hline 293.15 & 145.20 & 1.421 & 1578.50 & 162.43 & 0.807 & 854.84 & 165.94 & 1.363 & 1020.70 \\
\hline 298.15 & 146.83 & 1.406 & 1543.60 & 162.47 & 0.806 & 892.69 & 167.13 & 1.353 & 869.34 \\
\hline 303.15 & 147.80 & 1.396 & 1323.0 & 162.54 & 0.806 & 925.68 & 167.36 & 1.352 & 1192.50 \\
\hline 308.15 & 148.42 & 1.391 & 1547.50 & 16286 & 0.804 & 951.77 & 168.89 & 1.339 & 1344.00 \\
\hline 310.65 & 149.13 & 1.384 & 1542.10 & 164.65 & 0.796 & 890.29 & 169.50 & 1.335 & 1299.50 \\
\hline \multirow[t]{2}{*}{313.15} & 149.55 & 1.380 & 1548.40 & 165.15 & 0.793 & 895.03 & 170.86 & 1.324 & 1305.60 \\
\hline & \multicolumn{3}{|c|}{ 2-Propanol } & \multicolumn{3}{|c|}{ 1-Butanol } & \multicolumn{3}{|c|}{ 2-Butanol } \\
\hline 293.15 & 174.24 & 0.843 & 974.00 & 170.28 & 0.540 & 767.14 & 198.02 & 1.028 & 66.31 \\
\hline 298.15 & 174.36 & 0.843 & 1003.70 & 170.35 & 0.540 & 796.12 & 198.73 & 1.024 & 80.30 \\
\hline 303.15 & 174.85 & 0.840 & 1024.10 & 170.83 & 0.539 & 804.04 & 200.34 & 1.016 & 57.54 \\
\hline 308.15 & 174.95 & 0.840 & 1184.40 & 171.34 & 0.537 & 1000.70 & 201.19 & 1.011 & 65.76 \\
\hline 310.65 & 176.99 & 0.830 & 992.61 & 171.63 & 0.536 & 1010.0 & 201.44 & 1.010 & 75.99 \\
\hline 313.15 & 177.13 & 0.829 & 1005.20 & 172.11 & 0.535 & 1186.90 & 201.96 & 1.008 & 79.61 \\
\hline
\end{tabular}

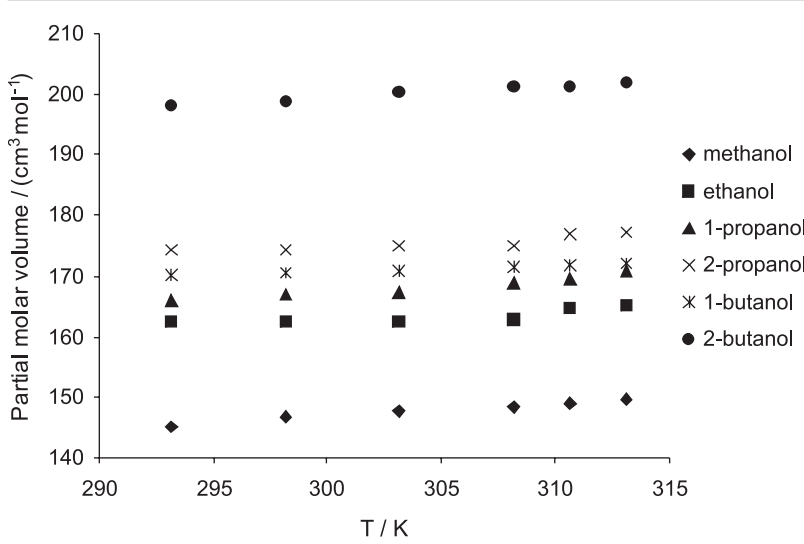

Figure 7. Partial molar volume $(\bar{V})$ as a function of temperature $(\mathrm{T})$ of mefenamic acid in different solvents.

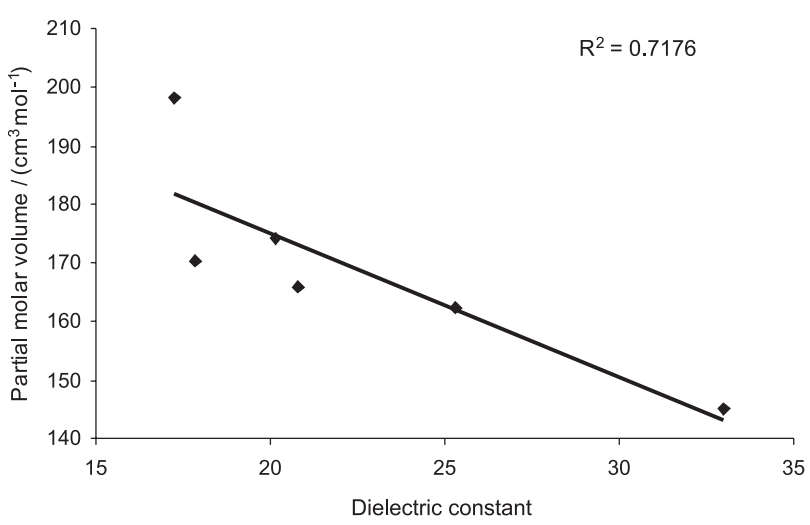

Figure 8. Partial molar volume $(\bar{V})$ at infinite dilution of mefenamic acid as a function of the dielectric constant of the solvent at $\mathrm{T}=293.15 \mathrm{~K}$.

to those obtained for methanol, ethanol, 2-propanol, 1-butanol (Table ). The increasing order of partial molar expansivity $\left(E_{2}^{0}\right)$ of mefenamic acid in different solvents represented as:

1-propanol $>$ 2-butanol $>$ methanol $>$ 2-propanol $>$ ethanol $>$ 1-butanol.
Table 9. Partial molar expansivity of mefenamic acid in different solvents

\begin{tabular}{lcc}
\hline Sr. No. & Solvents & $E_{2}^{0} /\left(\mathrm{cm}^{3} \mathrm{~mol}^{-1} \mathrm{~K}^{-1}\right)$ \\
\hline 1 & Methanol & 0.2035 \\
2 & Ethanol & 0.1310 \\
3 & 1-Propanol & 0.2262 \\
4 & 2-Propanol & 0.1469 \\
5 & 1-Butanol & 0.0920 \\
6 & 2-Butanol & 0.2064 \\
\hline
\end{tabular}

\section{Conclusions}

Partial molar volume of mefenamic acid is a function of temperature and increases linearly with temperature. When the solvent polarity was increased, partial molar volume showed a decreasing trend.

\section{References}

1. Iqbal, M.; Verrall, R. E.; J. Phys. Chem. 1987, 91, 967.

2. Katz, S.; Shinaberry, R. G.; Heck, E. L.; Squire, W.; Biochemistry 1980, 19, 3805.

3. Roth, S.H.; Annual Rev. Pharmacol. Toxicol. 1979, 19, 159.

4. Judis, J.; J. Pharm. Sci. 1980, 69, 885.

5. Iqbal, M.; Verrall, R. E.; Canadian J. Chem. 1989, 67, 727.

6. Iqbal, M. J.; Malik, Q. M.; J. Chem. Thermodynamics 2005 , 37, 1347.

7. Harned, H. S.; Owen, B. B.; The Physical Chemistry of Electrolyte Solution, Reinhold: New York, 1958.

8. Tanford, C.; Hydrophobic Effect: Formation of Micelles and Biological Membranes, $2^{\text {nd }}$ ed., Wiley-Interscience: New York, 1980.

9. Katzung, G. B.; Basic and Clinical Pharmacology, $4^{\text {th }}$ ed., Appleton \& Lange: California, 1989. 
10. Handbook of Chemistry \& Physics; Editor in Chief David R. Lide, $79^{\text {th }}$ ed., CRC: New York, 1998-1999.

11. Klotz, I. M.; Rosenberg, R. M.; Chemical Thermodynamics, Basic Theory and Methods, $3^{\text {rd }}$ ed., W. A. Benjamin: California, 1972, Ch.16.

12. Iqbal, M., Mateeullah, M.; Canadian J. Chem. 1990, 68, 725.

13. Rudan-Tasic, D.; Klofutar, C.; Monatsh. Chem. 1998, 129, 1245 .
14. Stolipin, V. F.; Mishustin, A. J.; J. Phys. Chem. (Russian) 1987, 61, 3226.

15. Gurney, R. W.; Ionic Processes in Solutions, McGraw Hill: New York, 1954.

16. Neal, J. L.; Goring, D. A. I.; J. Phys. Chem. 1970, 74, 658.

17. Reichardt, C.; Solvents and Solvent Effects in Organic Chemistry, $2^{\text {nd }}$ ed., VCH: Weinheim, 1988, Ch. 2.

Received: January 17, 2006 Published on the web: June 12, 2006 